\title{
A 19-Year Study of the Dynamics of an Invasive Alien Tree, Bischofia javanica, on a Subtropical Oceanic Island ${ }^{1}$
}

\author{
Kenji Hata, ${ }^{2,3}$ Jun-Ichirou Suzuki, ${ }^{3}$ Naoki Kachi, ${ }^{3}$ and Yasuo Yamamura ${ }^{4}$
}

\begin{abstract}
A 19-yr study of the dynamics of an invasive alien species, Bischofia javanica Blume, in a secondary forest was conducted in the Bonin Islands, Japan. The study was begun in 1984 when another alien species, Pinus luchuensis Mayer, had begun to die because of infection by a pine nematode as well as typhoon damage in 1983. Diameters at breast height (DBHs) of all trees in a 20 by $20 \mathrm{~m}$ plot and heights of all saplings $(<1.3 \mathrm{~m}, \geq 0.3 \mathrm{~m}$ in height $)$ were measured almost every 3 yr. The total basal area of $P$. luchuensis decreased over time, and all trees had fallen over by 1998. The total basal area of B. javanica increased more than 10-fold over $19 \mathrm{yr}$ without changes in tree or sapling density. Up to 1990, growth rates of trees of B. javanica were higher than those of two native canopy trees (Pouteria obovata and Machilus kobu), but a third native canopy tree (Schima mertensiana) had growth rates comparable with those of $B$. javanica. After 1990, there were few differences between growth rates of B. javanica and native species. However, mortality and recruitment of B. javanica were lower than those of native species of canopy trees during the survey period. The higher growth rate, lower mortality, and lower recruitment led to a shift from a skewed size distribution of the individuals of B. javanica toward a more bellshaped size distribution. Our results suggest that regeneration and maintenance of B. javanica populations in the secondary forests depend on canopy gaps occasionally created by disturbances.
\end{abstract}

OCEANIC ISLANDS ARE extremely vulnerable to invasions of human-introduced animals and plants. They often have received public attention as their endemic species are crowded out by the introduced species (Loope et al. 1988, Vitousek 1990). Recently, invasion by introduced alien species has be-

\footnotetext{
${ }^{1}$ This study was supported by a research project on Conservation Methods of Subtropical Island Ecosystems, headed by Seiichi Nohara, National Institute for Environmental Studies, Japan Environmental Agency. Manuscript accepted 12 December 2005.

${ }^{2}$ Corresponding author.

${ }^{3}$ Department of Biological Sciences, Graduate School of Science, Tokyo Metropolitan University, Minamiosawa 1-1, Hachioji, Tokyo, 192-0397, Japan (phone: +81-426-77-2585; fax: +81-426-77-2559; e-mail: ken-hata@comp.metro-u.ac.jp).

${ }^{4}$ Department of Environmental Science, Faculty of Science, Ibaraki University, Mito, Ibaraki, Japan.
}

Pacific Science (2006), vol. 60, no. 4:455-470

(C) 2006 by University of Hawai'i Press

All rights reserved come a priority concern for conservation biologists in many oceanic islands, such as the Hawaiian Islands (e.g., Huenneke 1990, Almasi 2000) and the Galápagos Islands (e.g., Itow 1995, Shimizu 1997).

Biological invasion by an alien species often facilitates invasion by other alien species (Mack and D'Antonio 1998, Parker et al. 1999, Simberloff and Von Holle 1999, Richardson et al. 2000) by changing a community or an ecosystem (Vitousek 1990, Vitousek et al. 1997, Levine et al. 2003). The facilitation of invasion may be caused by an increase in the amount of available resources (Davis et al. 2000). For example, damage to an established canopy structure by herbivory of an alien animal species or fire caused by flammable grasses increases the amount of available light for the understory vegetation, which often facilitates further invasions by other alien plants (e.g., Cross 1981, Hughes et al. 1991).

In an environment with abundant resources, alien plants often perform better 
than native plants (e.g., Caldwell et al. 1981, Williams and Black 1994, Pattison et al. 1998, Baruch and Goldstein 1999, Durand and Goldstein 2001). For example, the growth rates of seedlings of alien species are higher than those of natives in nutrient-rich soil (Fogarty and Facelli 1999, Milberg et al. 1999, Lowe et al. 2003), and the mortality rates of alien species can be lower (Goergen and Daehler 2002). The higher growth rates and/or lower mortality rates of the alien species enhance their establishment and dominance (e.g., Aplet et al. 1998, Gentle and Duggin 1998, Kolb et al. 2002).

In forests, canopy gaps increase the available light on the forest floor. Subsequent canopy closure by growth of the established plants reduces the amount of available light. Alien species that perform better than native species in environments with abundant resources (e.g., canopy gaps) may not be able to perform better than native species under a closed canopy. Indeed, relatively few alien plants seem to have the capacity to invade undisturbed native communities (Rejmánek 1989) due to high mortality (Mazia et al. 2001, Green et al. 2004) or low recruitment (Mazia et al. 2001, Bustamante and Simonetti 2005) and low growth rates (Green et al. 2004) in undisturbed native communities. Changes in the amount of available light on a forest floor by the opening and closing of canopy have substantial effects on the population dynamics of those alien species that perform better than native species under the canopy gap but do not perform well under the closed canopy. To quantify the effects of gap opening and closure on invasion, particularly for tree or long-lived species, it is necessary to analyze the long-term population dynamics of an alien species by repeated censuses.

An alien tree species, Bischofia javanica Blume (Euphorbiaceae), aggressively invades mesic sites in primary and secondary forests in the Bonin Islands, a subtropical oceanic archipelago in the Pacific, located about 1,000 $\mathrm{km}$ south of Tokyo and belonging to Japan (Shimizu 1988, Tanimoto and Toyoda 1996, Mueller-Dombois and Fosberg 1998). In particular, Bischofia seedlings frequently estab- lished and grew rapidly in forest gaps created by nematode-induced dieback of another alien tree, Pinus luchuensis Mayer (Pinaceae), which had previously been the dominant species in secondary forests. Therefore, we predicted that: (1) under a canopy gap created by the death of P. luchuensis, B. javanica would exhibit lower mortality as well as higher recruitment and growth rates than native species, and (2) under a subsequent closure of the canopy gap, B. javanica would exhibit higher mortality and lower recruitment and growth rates than native species, which would affect the community structure of the stand.

To test these predictions, we compared the population dynamics of $B$. javanica with that of native species in a secondary forest where many $P$. luchuensis died over a period of $19 \mathrm{yr}$.

\section{MATERIALS AND METHODS}

\section{Plant Species}

The alien tree species Bischofia javanica is a dioecious evergreen native to southern China, Taiwan, Southeast Asia, Fiji, Tonga, Samoa, and tropical Australia. The height of this species can be 15-20 m, with a trunk diameter of $1 \mathrm{~m}$ under favorable conditions. This species was introduced to the Bonin Islands in the early 1900s (Kimura 1986, Shimizu 1988) and by 1945 had been planted in at least 10 locations on Chichijima Island, the largest island in the archipelago (Toyoshima 1938, Mueller-Dombois and Fosberg 1998:234240). Thereafter, plants of this species spread into the surrounding mesic primary and secondary forests. Although this species is not a dominant component in a climax forest in its native region, it often appears even in climax forests in the Bonin Islands (Shimizu 1988, Tanimoto and Toyoda 1996).

Most of the mesic secondary forests on Chichijima Island became established after 1945 in abandoned fields, and they were dominated by the introduced species $P$. luchuensis and a native species, Schima mertensiana (Sieb. \& Zucc.) Koidz. (Theaceae) (Shimizu 1983). These forests are categorized as PinusSchima forest (Shimizu and Tabata 1991). In 
1979 a pine wood nematode, Bursaphelenchus xylophilus, was accidentally introduced to Chichijima Island, and almost all of the $P$. luchuensis trees were killed by 1984 (see photo 5. A5 in Mueller-Dombois and Fosberg 1998). In addition, a large typhoon in 1983 damaged the canopy of the secondary forests, which resulted in increases in amount of available light for the forest understory (Shimizu 1986). Relative light intensity on the forest floor of the Pinus-Schima forests where the pine nematode had killed the P. luchuensis rose by more than $50 \%$ after the typhoon in 1983 (Shimizu 2005). After the death of the P. luchuensis, most of the stands of the PinusSchima forests were composed mostly of $S$. mertensiana (Shimizu 1986), and B. javanica aggressively invaded some of these forests (Kimura 1986).

\section{Plot Establishment}

A permanent 20 by $20 \mathrm{~m}$ plot was established for long-term monitoring in 1984 in a forest in the Fukiagedani Valley $\left(27^{\circ} 04^{\prime} \mathrm{N}, 142^{\circ}\right.$ $12^{\prime}$ E, $120 \mathrm{~m}$ above sea level). Many B. javanica trees able to produce seeds were found around the plot, and dispersal and germination of seeds were often observed even in the plot. The plot also included some species that were principal components of secondary forests: Schima mertensiana, Pouteria obovata, Rhaphiolepis wrightiana, Machilus kobu, Ardisia sieboldii, Osmanthus insularis, and Ligustrum micranthum (Appendix 1). Most of the P. luchuensis trees had died but were standing in the plot in 1984. Some trees of B. javanica and other native species within or around the plot produced seeds. In this study, woody plants were categorized by their heights into three groups: trees $(\geq 1.3 \mathrm{~m})$, saplings $(<1.3$ $\mathrm{m}, \geq 0.3 \mathrm{~m})$, and seedlings $(<0.3 \mathrm{~m})$. All trees and saplings in the plot were tagged. The heights of all saplings and diameters at breast height (DBHs) of all trees were measured. The DBHs of the dead P. luchuensis trees were also measured to estimate their biomass when they were alive. Size remeasurements of the trees and saplings were carried out in winter or spring in 1987, 1990, 1995, 1998, 2000 , and 2003. Seedlings in the plot were tagged and counted in winter 1998, 2000, and 2003.

Relative photosynthetic photon flux densities under a closed canopy and under a gap were estimated from hemispherical photographs (Anderson 1964, Anderson and Miller 1974, Chazdon and Field 1987). The photographs were taken under a closed canopy within the plot at six points around noon on cloudy days in February 2000 using a camera (Nikon FE, Nikon, Tokyo, Japan) and $180^{\circ}$ angle lens (Fisheye-NIKKOR f8, Nikon, Tokyo, Japan). We did not investigate light environments in 1984. Instead, we took photographs under a gap near the plot created by the death of a P. luchuensis and assumed the light environment to be the same as that in 1984 under a canopy gap where a $P$. luchuensis had died. HemiView 2.1 Canopy Analysis Software (Delta-T Devices, Burwell, Cambridge, United Kingdom) was used to calculate the relative diffuse radiation at $0.5 \mathrm{~m}$ above ground level from the photographs.

\section{Additional Vegetation Surveys}

To more broadly describe species composition of the Pinus-Schima forests after death of $P$. luchuensis, we established 35 plots (100$400 \mathrm{~m}^{2}$; total area of the 35 plots was 0.4987 ha) in the secondary forests on Chichijima Island and measured diameters at $1.3 \mathrm{~m}$ above ground level (DBH) of all trees in 2000 and 2003.

\section{Data Analysis}

We compared $B$. javanica with principal native canopy tree species having niches that are likely to overlap with those of $B$. javanica in secondary forests. We defined three native species, S. mertensiana, P. obovata, and $M$. $k o b u$, as native canopy tree species because they included individuals larger than $25 \mathrm{~cm}$ DBH in the 35 Pinus-Schima forest plots (Appendix 3 ). In addition, the number of trees of these species in the 20 by $20 \mathrm{~m}$ permanent plot was large enough for statistical analyses. The three species were also categorized as canopy trees of the secondary forests by Shimizu and Tabata (1991). Although individuals 
of Livistona chinensis were larger than $25 \mathrm{~cm}$ $\mathrm{DBH}$, they were less likely to grow in diameter at breast height because they were monocots. Changes in basal area at $1.3 \mathrm{~m}$ above ground level, density, and size structure were compared between B. javanica and the three native canopy species for $19 \mathrm{yr}$. Mortality, recruitment, and growth rates were also compared between B. javanica and the three native species during each survey period. Mortality of trees between each survey period was calculated as the number of trees dying during a survey period divided by the number of trees at the beginning of a survey period. Recruitment of trees between each survey period was calculated as the number of trees recruited (i.e., exceeding $1.3 \mathrm{~m}$ height) during a survey period divided by the number of trees at the end of a survey period. Differences in mortality and recruitment of trees during each survey period between B. javanica and each of the three native species were analyzed by Fisher's exact probability test. Annual absolute growth rates in $\mathrm{DBH}\left(\mathrm{cm}\right.$ year $\left.{ }^{-1}\right)$ in each survey period were analyzed by oneway analysis of variance (ANOVA), and Holm's multiple test (Dalgaard 2002) was also conducted in all possible combinations of treatments. To evaluate changes in size structure of B. javanica and the three native canopy species for $19 \mathrm{yr}$, size distributions of $\mathrm{DBH}$ of $B$. javanica and the three native canopy species in 1984 were compared with those in 2003 by two-sample KolmogorovSmirnov test. All statistical analyses were carried out with the software R 2.0.1 (http:// www.r-project.org/).

\section{RESULTS}

\section{Changes in Basal Area and Relative Dominance}

In 1984 the basal area of the dead P. luchuensis trees was $34.9 \mathrm{~cm}^{2} \mathrm{~m}^{-2}$ and that of all live trees was $30.2 \mathrm{~cm}^{2} \mathrm{~m}^{-2}$. The basal area of all live trees had increased by 2003 (Figure 1a). However, the basal area of live P. luchuensis trees decreased because of death, and all $P$. luchuensis had fallen over by 1998 (Figure
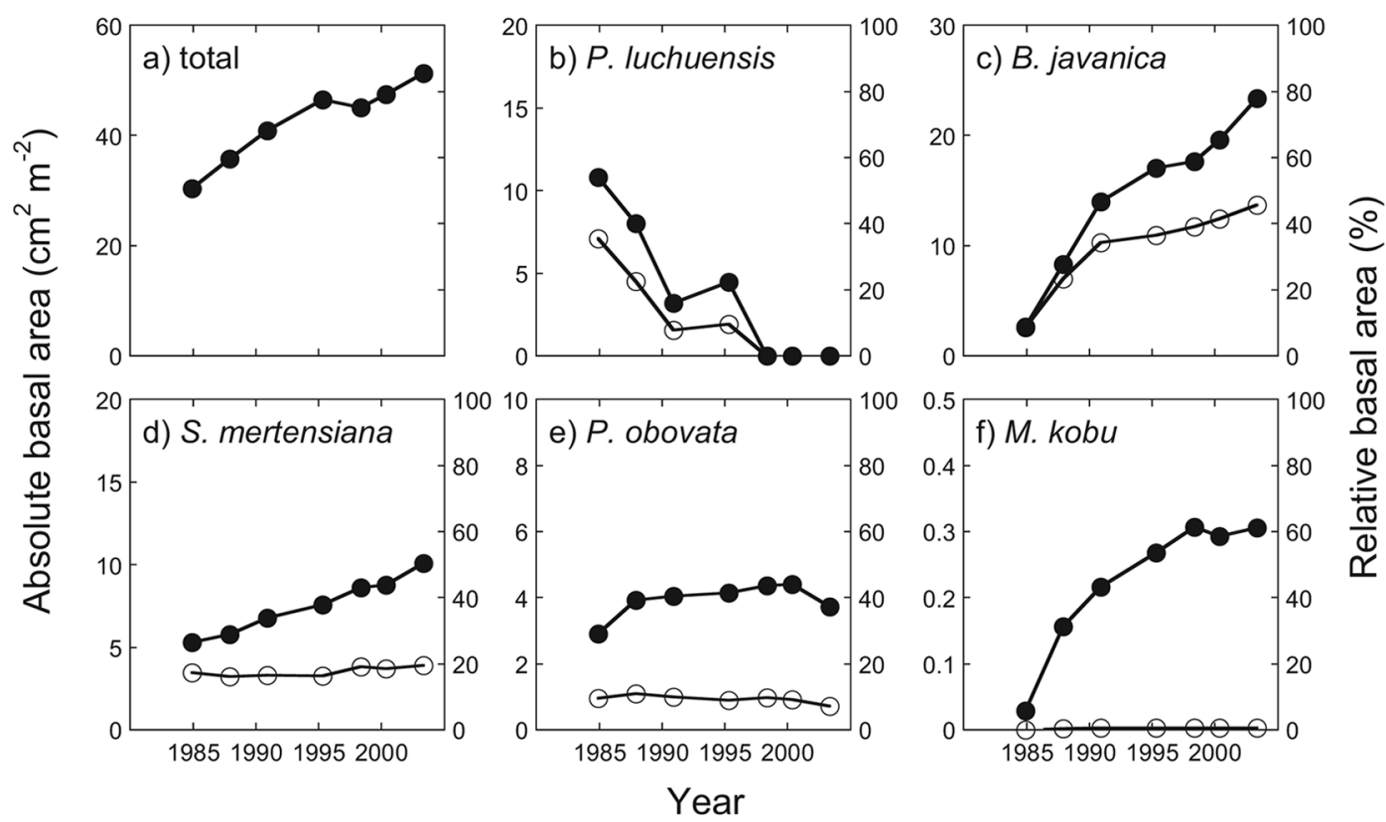

Figure 1. Changes in basal area of trees (>1.3 m height) in the permanent plot during $19 \mathrm{yr}: a$, total; $b$, P. luchuensis; $c$, B. javanica; $d, S$. mertensiana; $e, P$. obovata; $f, M$. kobu. Closed circles indicate absolute values and open circles indicate relative values of the total basal area. 
$1 b)$. The basal area of trees of B. javanica in 2003 was almost nine times larger than that in 1984 (Figure 1c). The relative dominance of B. javanica increased from $8.6 \%$ to $45.5 \%$ between 1984 and 2003. The basal area of other alien species other than B. javanica and $P$. luchuensis was low and changed very little during the $19 \mathrm{yr}$ (Appendix 1).

More than $75 \%$ of the basal area consisted of native tree species Schima mertensiana, Pouteria obovata, and Rhaphiolepis wrightiana (Appendix 1). Basal area of S. mertensiana in 2003 was 1.9 times as large as that in 1984 , but its relative dominance did not change in the 19 yr (Figure $1 d$ ). Small changes in the basal area of $P$. obovata were observed over the 19 yr (Figure 1e). The basal area of Macbilus $k o b u$ was low, but it increased constantly over $19 \mathrm{yr}$ (Figure $1 f$ ).

\section{Changes in Densities of Trees, Saplings, and Seedlings}

The total number of trees markedly increased from 1984 to 1990 and decreased slightly after
1990 (Figure 2a). The number of $P$. luchuensis trees gradually decreased, and all had disappeared by 1998 (Figure 2b). There were only small changes in the number of $B$. javanica trees, and B. javanica represented ca. $40 \%$ of all trees in the plot over the $19 \mathrm{yr}$ (Figure 2c). The number of trees of $S$. mertensiana increased, and the relative dominance increased from $3.2 \%$ to $6.5 \%$ between 1984 and 2003 (Figure $2 d$ ). The numbers of trees of $P$. obovata and M. kobu increased from 1984 to 1990 but decreased after 1990 (Figure $2 e, f$ ). The relative densities of trees of the two native species did not change between 1984 and 2003.

The total number of saplings of all species decreased from 1984 to 1995, increased from 1995 to 2000, and decreased again toward 2003 (Figure $3 a$ ). More than $70 \%$ of the total number of saplings consisted of three dominant native species, $R$. wrightiana, Ligustrum micranthum, and P. obovata, over the $19 \mathrm{yr}$ (Appendix 2). The percentage of saplings of B. javanica was not larger than $10 \%$ of the total number of saplings, decreased rapidly
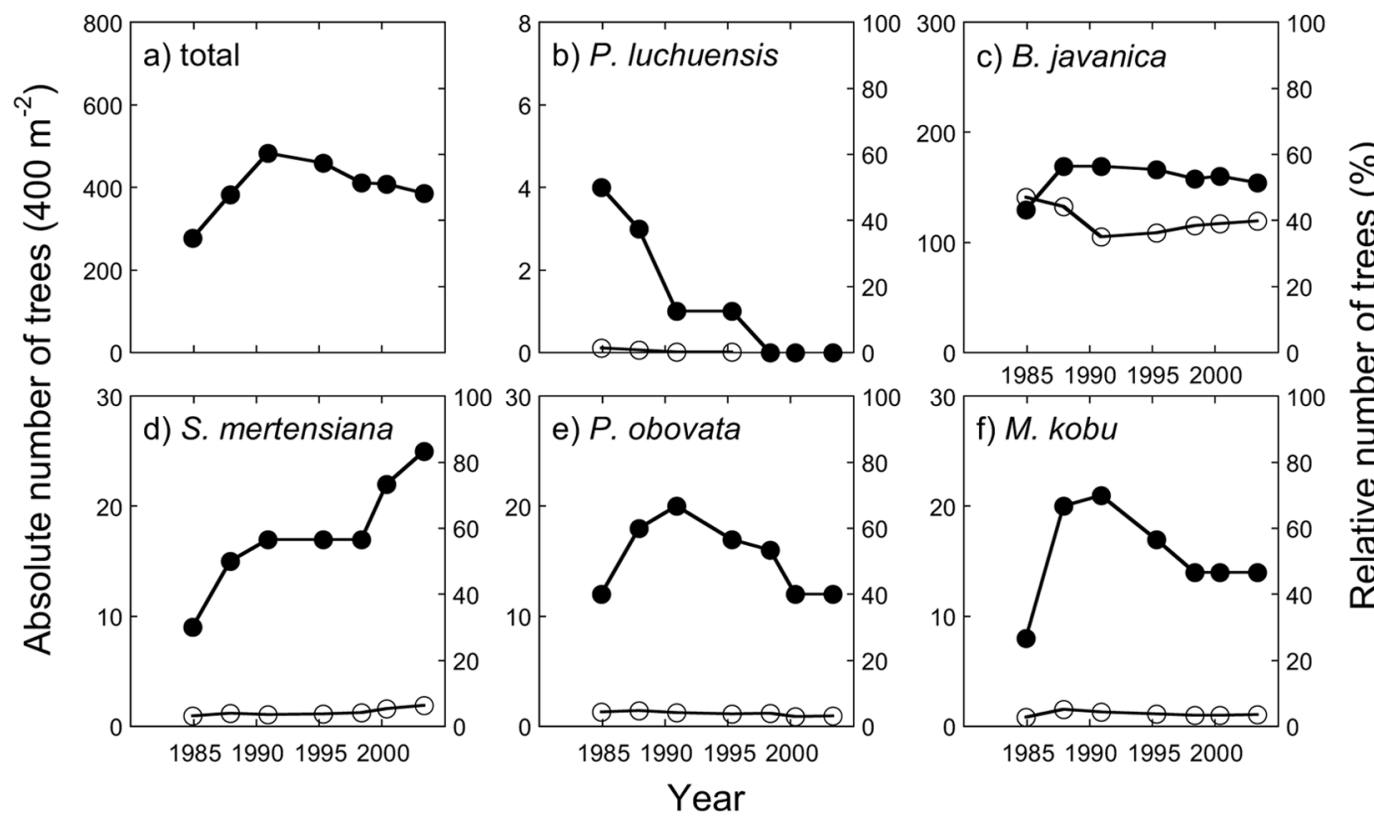

FIGURE 2. Changes in the number of trees in the permanent plot during $19 \mathrm{yr}: a$, total; $b, P$. luchuensis; $c$, B. javanica; $d$, $S$. mertensiana; $e$, P. obovata; $f, M$. kobu. Closed circles indicate absolute values and open circles indicate relative values. 


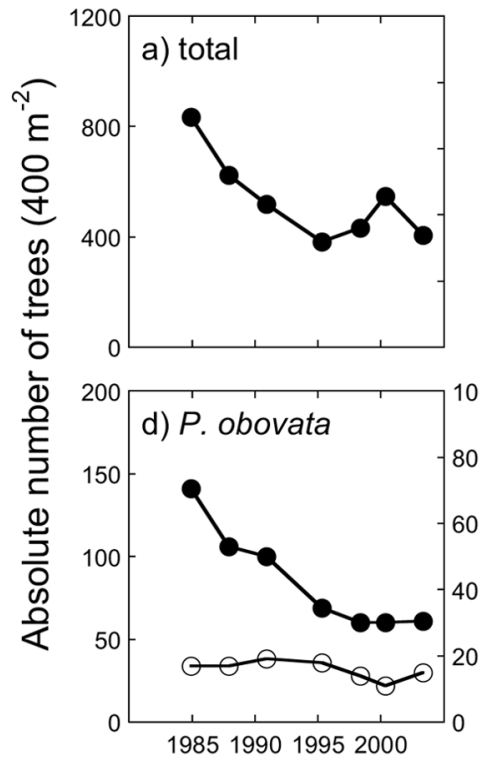

1985199019952000
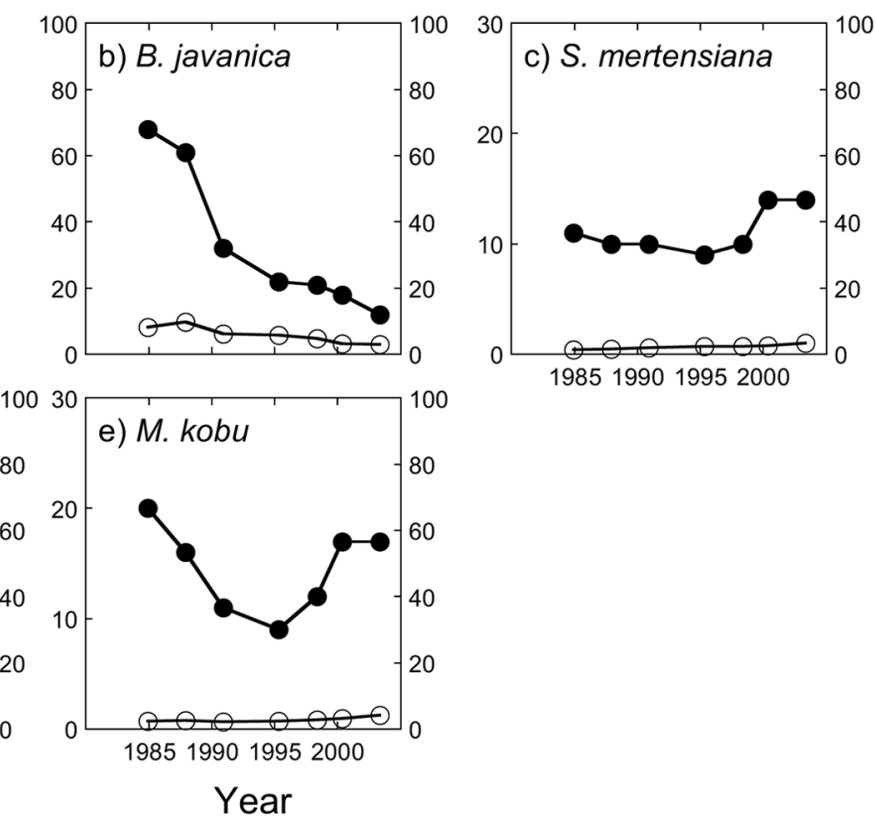

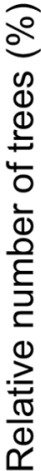

Figure 3. Changes in the number of saplings in the permanent plot during $19 \mathrm{yr}: a$, total; $b$, B. javanica; $c$, S. mertensi$a n a ; d, P$. obovata; $e, M$. kobu. Closed circles indicate absolute values and open circles indicate relative values.

between 1984 and 1987, and then decreased steadily through 2003 (Figure 3b). Number of saplings of $S$. mertensiana was $1.3 \%$ of the total numbers of saplings and did not change during $19 \mathrm{yr}$ (Figure 3c). The number of saplings of $P$. obovata decreased over $19 \mathrm{yr}$ (Figure $3 d$ ). The number of saplings of $M$. kobu decreased between 1984 and 1995 and then increased after 1995 (Figure 3e). No saplings of $P$. luchuensis were observed in the permanent plot during the $19 \mathrm{yr}$.

In the permanent plot, seven seedlings of B. javanica were counted in 1998, 146 in 2000 , and 12 in 2003. Most seedlings of native species belonged to $R$. wrightiana, L. micranthum, or $P$. obovata. In 1998, 63 seedlings of $P$. obovata were noted, 63 in 2000, and 52 in 2003. There were few seedlings of S. mertensiana and M. kobu.

\section{Changes in Size Structure}

There were only four living P. luchuensis trees in 1984, and their DBHs were all larger than
$16 \mathrm{~cm}$. They had died by 1998 , and no recruitment of P. luchuensis occurred after 1984 in the permanent plot. All of the B. javanica trees were smaller than $8 \mathrm{~cm}$ DBH in 1984 except for one individual $(\mathrm{DBH}=17.7 \mathrm{~cm})$, and the size distribution was weakly skewed (Figure 4a). Between 1984 and 2003, the size distribution of $B$. javanica became increasingly bell-shaped, and it changed significantly (two-sample Kolmogorov-Smirnov test, $D=0.63, P<0.001$ ). Size distributions of $S$. mertensiana and $P$. obovata were various but more evenly distributed throughout the sizes (Figure $4 b, c$ ). No significant change in the size distributions of $S$. mertensiana and P. obovata was observed between 1984 and 2003 (two-sample Kolmogorov-Smirnov test, $D=0.30, P=0.41$ and $D=0.42, P=0.26$, respectively). Diameters at breast height of all $M$. kobu trees were smaller than $4 \mathrm{~cm}$ in 1984, and the size distribution of the species was L-shaped in 1984 and throughout the 19-yr study period (two-sample KolmogorovSmirnov test, $D=0.59, P=0.059$ ) (Figure $4 d)$. 

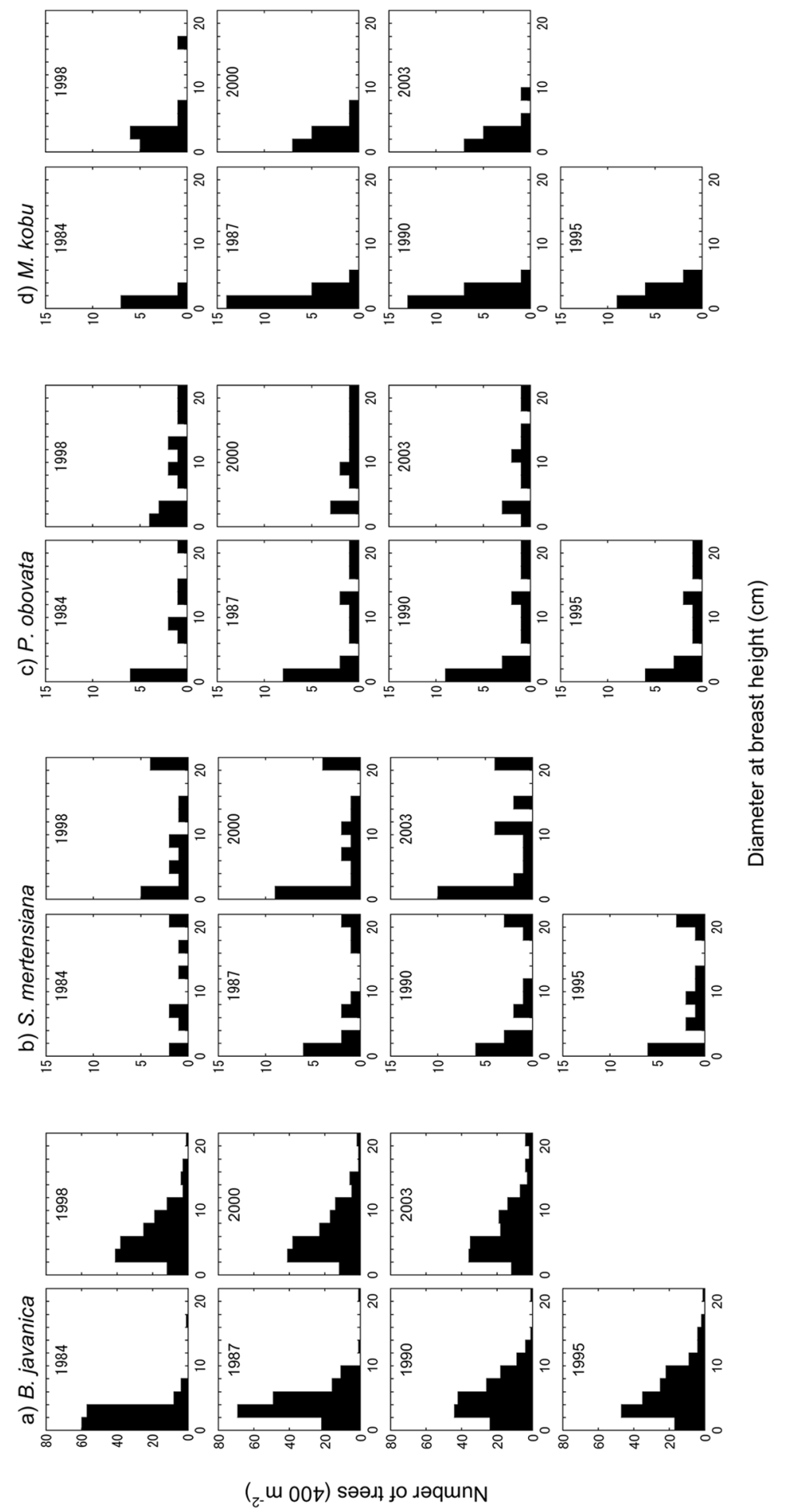
TABLE 1

Mortality of Trees of B. javanica and Three Native Canopy Species in Two DBH Size Classes between Survey Periods

\begin{tabular}{|c|c|c|c|c|c|c|c|c|}
\hline \multirow{2}{*}{$\frac{\text { DBH Size }}{<8 \mathrm{~cm}}$} & \multirow{2}{*}{$\begin{array}{c}\text { Survey Period } \\
1984-1990\end{array}$} & \multirow{2}{*}{$\frac{\text { B. javanica }}{0.054}$} & \multicolumn{2}{|c|}{ S. mertensiana } & \multicolumn{2}{|c|}{ P. obovata } & \multicolumn{2}{|c|}{ M. kobu } \\
\hline & & & 0 & n.s. & 0 & n.s. & 0.125 & n.s. \\
\hline & 1990-1995 & 0.037 & 0.091 & n.s. & 0.385 & $* * *$ & 0.190 & * \\
\hline & $1995-2000$ & 0.113 & 0 & n.s. & 0.600 & $* * *$ & 0.353 & * \\
\hline & $2000-2003$ & 0.061 & 0.077 & n.s. & 0 & n.s. & 0.071 & n.s. \\
\hline \multirow[t]{4}{*}{$>8 \mathrm{~cm}$} & $1984-1990$ & 0 & 0 & n.s. & 0 & n.s. & & \\
\hline & 1990-1995 & 0 & 0 & n.s. & 0 & n.s. & & \\
\hline & $1995-2000$ & 0.024 & 0 & n.s. & 0 & n.s. & & \\
\hline & $2000-2003$ & 0 & 0 & n.s. & 0.125 & n.s. & & \\
\hline
\end{tabular}

*, $P<0.05 ;{ }^{* * *}, P<0.001 ;$ n.s., not significant between $B$. javanica and each of the three native canopy species by Fisher's exact probability test.

TABLE 2

Recruitment of Trees of B. javanica and Three Native Canopy Species between Survey Periods

\begin{tabular}{|c|c|c|c|c|c|c|c|}
\hline \multirow{2}{*}{$\frac{\text { Survey Period }}{1984-1990}$} & \multirow{2}{*}{$\frac{\text { B. javanica }}{0.272}$} & \multicolumn{2}{|c|}{ S. mertensiana } & \multicolumn{2}{|c|}{ P. obovata } & \multicolumn{2}{|c|}{ M. kobu } \\
\hline & & 0.471 & n.s. & 0.400 & n.s. & 0.667 & $* * *$ \\
\hline 1990-1995 & 0.012 & 0.059 & n.s. & 0.118 & * & 0 & n.s. \\
\hline $1995-2000$ & 0.056 & 0.227 & * & 0.083 & n.s. & 0.214 & n.s. \\
\hline $2000-2003$ & 0.006 & 0.160 & ** & 0.083 & n.s. & 0.071 & n.s. \\
\hline
\end{tabular}

${ }^{*}, P<0.05 ;{ }^{* *}, P<0.01$; ${ }^{* *}, P<0.001$; n.s., not significant between $B$. javanica and each of the three native canopy species by Fisher's exact probability test.

\section{Mortality, Recruitment, and Growth}

Mortality of B. javanica trees smaller than 8 $\mathrm{cm}$ DBH was not different from that of $S$. mertensiana smaller than $8 \mathrm{~cm}$ DBH during the $19 \mathrm{yr}$ and significantly lower than that of P. obovata and M. kobu between 1990 and 2000 (Table 1). Mortality of B. javanica, $S$. mertensiana, and $P$. obovata larger than $8 \mathrm{~cm}$ DBH was very low, and there were no significant differences between $B$. javanica and the two native species during the $19 \mathrm{yr}$.

Almost no recruitment of $B$. javanica occurred except for the period between 1984 and 1990. Recruitment rate of B. javanica was significantly lower than that of $S$. mertensiana after 1995 (Table 2). The recruitment rate of B. javanica was also significantly lower than that of $P$. obovata between 1990 and 1995 and that of M. kobu between 1984 and 1990.

Absolute growth rates of $B$. javanica trees smaller than $8 \mathrm{~cm} \mathrm{DBH}$ were $0.55 \mathrm{~cm} \mathrm{yr}^{-1}$ between 1984 and 1990 but decreased after 1990 (Table 3). There were no significant differences in absolute growth rates between B. javanica and S. mertensiana until 1990. Absolute growth rates of $P$. obovata and M. kobu were lower than those of B. javanica until 1990, although there were no significant differences between growth rates of B. javanica and M. kobu. After 1990, absolute growth rates of $B$. javanica and the two native species were similar. No significant difference in absolute growth rates of trees larger than $8 \mathrm{~cm}$ DBH were observed between $B$. javanica and native species except between 1995 and 2000.

\section{Light Conditions}

In February 2000, the mean of the relative diffuse radiation at $0.5 \mathrm{~m}$ above ground level under a closed canopy was estimated as $1.72 \%$, and that in a canopy gap as $23.69 \%$. The mean of the relative diffuse radiation in 
TABLE 3

Mean $( \pm \mathrm{SE})$ of Absolute Growth Rate $(\mathrm{cm} / \mathrm{yr})$ of Trees of B. javanica and Two Native Canopy Species in Two DBH Size Classes between Survey Periods

\begin{tabular}{lccccc}
\hline \hline DBH Size & Survey Period & B. javanica & S. mertensiana & P. obovata & M. kobu \\
\hline$<8 \mathrm{~cm}$ & $1984-1990$ & $0.55 \pm 0.03 \mathrm{a}$ & $0.46 \pm 0.13 \mathrm{a}$ & $0.006 \pm 0.04 \mathrm{~b}$ & $0.28 \pm 0.07 \mathrm{a}$ \\
& $1990-1995$ & $0.09 \pm 0.02 \mathrm{a}$ & $0.55 \pm 0.03 \mathrm{a}$ & $0.02 \pm 0.01 \mathrm{a}$ & $0.05 \pm 0.04 \mathrm{a}$ \\
& $1995-2000$ & $0.05 \pm 0.01 \mathrm{a}$ & $0.20 \pm 0.07 \mathrm{~b}$ & $0.01 \pm 0.02 \mathrm{ab}$ & $0.06 \pm 0.03 \mathrm{ab}$ \\
$>8 \mathrm{~cm}$ & $2000-2003$ & $0.05 \pm 0.03 \mathrm{a}$ & $0.06 \pm 0.05 \mathrm{a}$ & $-0.06 \pm 0.05 \mathrm{a}$ & $0.03 \pm 0.04 \mathrm{a}$ \\
& $1984-1990 \ddagger$ & 2.13 & $0.43 \pm 0.05$ & $0.07 \pm 0.10$ & \\
& $1990-1995$ & $0.25 \pm 0.05 \mathrm{a}$ & $0.29 \pm 0.03 \mathrm{a}$ & $0.03 \pm 0.03 \mathrm{a}$ & \\
& $1995-2000$ & $0.18 \pm 0.03 \mathrm{a}$ & $0.35 \pm 0.07 \mathrm{~b}$ & $0.04 \pm 0.04 \mathrm{a}$ & \\
& $2000-2003$ & $0.39 \pm 0.05 \mathrm{a}$ & $0.42 \pm 0.09 \mathrm{a}$ & $0.04 \pm 0.02 \mathrm{a}$ & \\
\hline
\end{tabular}

Values followed by different letters indicate significantly different $(P<0.05)$ treatment means based on Holm's multiple test following ANOVA.

$\ddagger$ Sample size too small for statistical test.

the canopy gap near the study plot was 14 times higher than that under the closed canopy.

\section{Additional Vegetation Surveys}

Surveys of the former Pinus-Schima forests across broader areas in 2000 and 2003 showed that the forest consisted of native tree species S. mertensiana, Pouteria obovata, Machilus kobu, Elaeocarpus photiniifolius, and Livistona chinensis. Native species of shrubs such as Rhaphiolepis wrigbtiana, Ligustrum micranthum, Ardisia sieboldii, and Osmanthus insularis were also included. In some of the 35 plots, Bischofia javanica dominated the canopy layer, and an alien species, Psidium cattleianum, occurred in the shrub layer. There were no differences in species composition between the 20 by $20 \mathrm{~m}$ permanent plot and the 35 additional survey plots (Appendix 3). It is, therefore, likely that the changes documented in the 20 by $20 \mathrm{~m}$ permanent plot are representative of the Pinus-Schima forests that were aggressively invaded by $B$. javanica after death of $P$. luchuensis.

\section{DISCUSSION}

Death of P. luchuensis after infection by a pine nematode combined with damage from a large typhoon in 1983 produced many canopy gaps in Pinus-Schima forests. High relative diffuse radiation measured in a canopy gap created by death of P. luchuensis in 2000 implies that the death of $P$. luchuensis probably also caused marked increases in radiation on the forest floor in the study plot.

For several years after the typhoon in 1983, the relative light intensity on the forest floor of Pinus-Schima forests decreased due to growth of sedges, ferns, and large saplings of tree species, and the light conditions on the forest floor became more or less the same as before the death of $P$. luchuensis (Shimizu 2005). Because there were no dead trees larger than $20 \mathrm{~cm} \mathrm{DBH}$ in the plot except for $P$. luchuensis during the study period (data not presented), it is unlikely that the death of trees other than $P$. lucbuensis contributed significantly to increases in light availability. Low relative diffuse radiation under a closed canopy in the plot in 2000 implies that from 1984 to 2003 the decrease in light by closure of canopy was associated with an increase in the basal areas by regrowth of all alien and native woody species except $P$. luchuensis.

In pot-culture experiments that suddenly increased light availability from shade to full sun, seedlings of B. javanica and S. mertensiana exhibited rapid photosynthetic acclimation in shade leaves by minimizing photoinhibition while also rapidly developing new sun leaves with high photosynthetic capacity, in comparison with other pioneer and late-successional species in the Bonin Islands 
(Yamashita et al. 2000). This may have enabled higher growth rates of $B$. javanica trees in the smaller size classes than native canopy tree species except for $S$. mertensiana until 1990, when the forest gaps caused by the death of $P$. luchuensis trees had substantially closed. On the other hand, growth rates of larger trees of $B$. javanica did not differ from rates of native canopy tree species, which indicates that there were little differences in growth between $B$. javanica and native canopy tree species once they reached the forest canopy.

The numbers of saplings and small trees of $B$. javanica decreased because of no recruitment from $B$. javanica seedlings during this time. In and around the study plot, there were several B. javanica trees producing seeds (K.H., pers. obs.). Therefore, seed dispersal and germination of seeds could potentially occur in the plot, and germination of B. javanica was, indeed, often observed in the study plot during the survey period. However, there were few established seedlings of $B$. $j a$ vanica over the $19 \mathrm{yr}$. Although seeds of $B$. $j a$ vanica can germinate even on a shaded forest floor under a dense canopy, whether or not germinated seedlings can establish depends on the amount of available light (Tanimoto and Toyoda 1996). Thus, the seedlings of $B$. javanica that germinated under a dense canopy are less likely to establish and grow. Closure of a canopy gap appears to prevent seedlings of $B$. javanica from establishing. Thus B. javanica, like Pinus, appears to be a shade-intolerant pioneer species.

Low mortality of $B$. javanica at small size, as compared with other native canopy tree species except for $S$. mertensiana, indicates that most individuals of $B$. javanica existing during the survey period probably established in an environment in which available light was adequate. Indeed, $88.4 \%$ of $B$. javanica individuals existing in the survey period established before 1987. This suggests that the first $B$. javanica need a canopy opening for establishment, and thereafter when advanced in growth they can survive under even a closed canopy. In a primary forest of the Bonin Islands, large saplings of $B$. javanica are able to survive under even a dense canopy (Shimizu
1988). Seedlings of B. javanica have physiological and morphological acclimation capacity in their leaves to high or low light conditions in comparison with several native dominant species found in early, mid-, and late-successional stages in the primary forest of the Bonin Islands (Yamashita et al. 2002). The high acclimation capacity of B. javanica may enable lower mortality of small trees as compared with some native species that dominate the forest even under a closed canopy.

Our results suggest that establishment of $B$. javanica depends on whether seeds of $B$. javanica can germinate and grow under a canopy gap before the canopy closure. Seedlings and saplings of $B$. javanica exhibit greater growth than native canopy tree species except for S. mertensiana under a canopy gap. Although there were few differences in growth between smaller trees of $B$. javanica and that of natives under a closed canopy, they show lower mortality than natives except for $S$. mertensiana. Regeneration and maintenance of the B. javanica population in the secondary forest depends on the frequency and intensity of disturbance. Forests in the Bonin Islands have been disturbed occasionally by typhoons or severe drought in the last $30 \mathrm{yr}$ (Oka et al. 2000). Therefore, the forests in the Islands are likely to be subjected to disturbances in the future, which would allow the establishment and reproduction of $B$. javanica in the secondary forest.

Species richness of native tree species at the stand invaded by B. javanica in the PinusSchima forest after death of $P$. luchuensis was significantly lower than at sites where $B . j a-$ vanica had not invaded, which is likely to be due to strong negative correlations between distribution patterns of individuals of $B$. javanica and those of principal native tree species (K.H., unpubl. data). If the negative correlations are due to prevention of establishment of native species by $B$. javanica, then establishment and reproduction of $B$. javanica in the secondary forest may directly prevent the establishment of native tree species. However, increases in basal areas of many native species (Appendix 1) and frequent recruitment of several species such as $R$. wrightiana and L. micranthum (data not presented) oc- 
curred even when B. javanica was present, and species richness of native species in our permanent study plot did not change during the survey period (Appendix 1 and 2). These results indicate that competition between $B$. javanica and native species during the survey period may have been weak because many vacant niches existed after the death of $P$. $l u$ chuensis. Our study period may have been too short to clarify effects of B. javanica on population dynamics of native species in the secondary forests. To clarify the effects, it is necessary to conduct a more long-term survey and also compare our results with the population dynamics of native species in the secondary forests that $B$. javanica did not invade.

Finally, it is interesting to note that an alien pine nematode that was introduced accidentally plays a key role as an unintended bicontrol agent for P. luchuensis. However, effects of $P$. luchuensis on native species in the secondary forest were minor because it appeared to occupy a vacant niche in the Bonin Islands, where there had been no native species with a growth form and physical features like pines (Shimizu and Tabata 1985). Nevertheless, the pine nematode may have substantial effects on native species in the secondary forest because basal area of native species in our study plot increased after death of $P$. $l u$ chuensis.

\section{ACKNOWLEDGMENTS}

We thank the Environmental Agency and the Department of National Forests in the Ogasawara Islands for permission to conduct this study on the plants of Chichijima Island. We are grateful to Masae Shiyomi, Yoshimichi Hori, Shinpei Sudo, Wakio Kimura, Satoru Honma, Takenao Takahashi, Atsushi Ishida, Takashi Nakano, Naoko Yamashita, and Keiichiro Yoshida for valuable discussion of the manuscript. Yoshikazu Shimizu kindly provided an unpublished manuscript and data about changes in light environments on the forest floor of Pinus-Schima secondary forests. Judy Noguchi edited the English of the manuscript. Three anonymous referees made numerous valuable comments that im- proved our original manuscript. This study was originally organized by the late Professor Emeritus Makoto Kimura and the late Masaki Funakoshi.

\section{Literature Cited}

Almasi, K. N. 2000. A non-native perennial invades a native forest. Biol. Invas. 2:219230.

Anderson, M. C. 1964. Studies of the woodland light climate. II. Seasonal variation in the light climate. J. Ecol. 52:643-663.

Anderson, M. C., and E. E. Miller. 1974. Forest cover as a solar camera: Penumbral effects in plant canopies. J. Appl. Ecol. 11:691-697.

Aplet, G. H., R. F. Hughes, and P. M. Vitousek. 1998. Ecosystem development on Hawaiian lava flows: Biomass and species composition. J. Veg. Sci. 9:17-26.

Baruch, Z., and G. Goldstein. 1999. Leaf construction cost, nutrient concentration, and net $\mathrm{CO}_{2}$ assimilation of native and invasive species in Hawaii. Oecologia (Berl.) 121:183-192.

Bustamante, R. O., and J. A. Simonetti. 2005. Is Pinus radiata invading the native vegetation in central Chile? Demographic responses in a fragmented forest. Biol. Invas. 7:243-249.

Caldwell, M. M., J. H. Richards, D. A. Johnson, R. S. Nowak, and R. S. Dzurec. 1981. Coping with herbivory: Photosynthetic capacity and resource allocation in two semiarid Agropyron bunchgrasses. Oecologia (Berl.) 50:14-24.

Chazdon, R. L., and C. B. Field. 1987. Photographic estimation of photosynthetically active radiation: Evaluation of a computerized technique. Oecologia (Berl.) 73:525532.

Cross, J. R. 1981. The establishment of Rhododendron ponticum in the Killarney Oakwood, S.W. Ireland. J. Ecol. 69:807-824.

Dalgaard, P. 2002. Introductory statistics with R. Springer, New York.

Davis, M. A., J. P. Grime, and K. Thompson. 2000. Fluctuating resources in plant communities: A general theory of invasibility. J. Ecol. 88:528-534. 
Durand, L. Z., and G. Goldstein. 2001. Photosynthesis, photoinhibition, and nitrogen use efficiency in native and invasive tree ferns in Hawaii. Oecologia (Berl.) 126: 345-354.

Fogarty, G., and J. M. Facelli. 1999. Growth and competition of Cytisus soparius, an invasive shrub, and Australian native shrubs. Plant Ecol. 144:27-35.

Gentle, C. B., and J. A. Duggin. 1998. Interference of Choricarpia leptopetala by Lantana camara with nutrient enrichment in mesic forests on the central coast of NSW. Plant Ecol. 136:205-211.

Goergen, E., and C. C. Daehler. 2002. Factors affecting seedling recruitment in an invasive grass (Pennisetum setaceum) and a native grass (Heteropogon contortus) in the Hawaiian Islands. Plant Ecol. 161:147156.

Green, P. T., P. S. Lake, and D. J. O'Dowd. 2004. Resistance of island rainforest to invasion by alien plants: Influence of microhabitat and herbivory on seedling performance. Biol. Invas. 6:1-9.

Huenneke, L. F. 1990. Seedling and clonal recruitment of the invasive tree Psidium cattleianum: Implications for management of native Hawaiian forests. Biol. Conserv. 53:199-211.

Hughes, F., P. M. Vitousek, and T. Tunison. 1991. Alien grass invasion and fire in the seasonal submontane zone of Hawai'i. Ecology 72:743-746.

Itow, S. 1995. Phytogeography and ecology of Scalesia (Compositae) endemic to the Galápagos Islands. Pac. Sci. 49:17-30.

Kimura, M. 1986. On the invasion of introduced tree species Bischofia javanica into the native vegetation of Bonin (Ogasawara) Islands. Pages 10-13 in Research Related to the UNESCO's Man and the Biosphere Programme in Japan, 19851986. Committee on MAB Programme.

Kolb, A., P. Alpert, D. Enters, and C. Holzapfel. 2002. Patterns of invasion within a grassland community. J. Ecol. 90:871881.

Levine, J. M., M. Vilá, C. M. D'Antonio, J. S. Dukes, K. Grigulis, and S. Lavorel. 2003.
Mechanisms underlying the impacts of exotic plant invasions. Philos. Trans. R. Soc. Lond. B Biol. Sci. 270:775-781.

Loope, L. L., O. Hamann, and C. P. Stone. 1988. Comparative conservation biology of oceanic archipelagoes. BioScience 38: 272-282.

Lowe, P. N., W. K. Lauenroth, and I. C. Burke. 2003. Effects of nitrogen availability on competition between Bromus tectorum and Bouteloua gracilis. Plant Ecol. 167:247-254.

Mack, M. C., and C. M. D’Antonio. 1998. Impacts of biological invasions on disturbance regimes. Trends Ecol. Evol. 13: 195-198.

Mazia, C. M., E. J. Chaneton, C. M. Ghersa, and R. J. C. León. 2001. Limits to tree species invasion in pampean grassland and forest plant communities. Oecologia (Berl.) 128:594-602.

Milberg, P., B. B. Lamont, and M. A. PérezFernández. 1999. Survival and growth of native and exotic composites in response to a nutrient gradient. Plant Ecol. 145:125-132.

Mueller-Dombois, D., and F. R. Fosberg. 1998. Vegetation of the tropical Pacific islands. Springer, New York.

Oka, S., K. Yoshida, H. Iwashita, Y. Iijima, and T. Satoh. 2000. Interannual variability of the hydroclimatic environment, based on the water balance at Chichi-jima Island in the Bonin (Ogasawara) Islands. Ogasawara Res. 26:15-33.

Parker, I. M., D. Simberloff, W. M. Lonsdale, K. Goodell, M. Wonham, P. M. Kareiva, M. H. Williamson, B. Von Holle, P. B. Moyle, J. E. Byers, and L. Goldwasser. 1999. Impact: Toward a framework for understanding the ecological effects of invaders. Biol. Invas. 1:3-19.

Pattison, R. R., G. Goldstein, and A. Ares. 1998. Growth, biomass allocation and photosynthesis of invasive and native $\mathrm{Ha}$ waiian rainforest species. Oecologia (Berl.) 117:449-459.

Rejmánek, M. 1989. Invasibility of plant communities. Pages 369-388 in J. A. Drake, H. A. Mooney, F. Castri, R. H. di 
Groves, F. J. Kruger, M. Rejmánek, and M. Williamson, eds. Biological invasions: A global perspective. Wiley, Chichester.

Richardson, D. M., N. Allsopp, C. M. D'Antonio, S. J. Milton, and M. Rejmánek. 2000. Plant invasions - the role of mutualisms. Biol. Rev. 75:65-93.

Shimizu, Y. 1983. Plant ecological studies of the forest in the Bonin (Ogasawara) Islands [in Japanese]. Ph.D. diss., Kyoto University, Kyoto.

1986. Serious damage to Pinus lutchuensis by the attack of the pine wood nematode at Chichijima in the Bonin (Ogasawara) Islands. J. Fac. Lett. Komazawa Univ., Tokyo 44:169-178.

. 1988. Vegetation of Mt. Kuwanoki in the Bonin (Ogasawara) Islands with reference to the invasion of an introduced tree species (Bischofia javanica) [in Japanese]. Regional Rev. (Inst. for Appl. Geogr., Komazawa Univ., Tokyo) 1:3146.

. 1997. Comparative relationships between tree species of Scalesia (S. pedunculata, S. cordata, S. microphylla) and introduced plants (Cinchona succirubra, Psidium guajava, Lantana camara) with reference to regeneration mechanism of Scalesia forests in the Galápagos Islands. Regional Rev. (Inst. for Appl. Geogr., Komazawa Univ., Tokyo) 8:145-169.

. 2005. A vegetation change during a 20-year period following two continuous disturbances (mass-dieback of pine trees and typhoon damage) in the Pinus-Schima secondary forest on Chichijima in the Ogasawara (Bonin) Islands: Which won, advanced saplings or new seedlings. Ecol. Res. 20:708-725.

Shimizu, Y., and H. Tabata. 1985. Invasion of Pinus luchuensis and its influence on the native forest on a Pacific island. J. Biogeogr. 12:195-207.

1991. Forest structures, composition, and distribution on a Pacific island, with reference to ecological release and speciation. Pac. Sci. 45:28-49.

Simberloff, D., and B. Von Holle. 1999. Positive interactions of nonindigenous species: Invasional meltdown? Biol. Invas. 1:21-32.

Tanimoto, T., and T. Toyoda. 1996. Survivorship and growth of Akagi (Bischofia javanica $\mathrm{BI}$ ) seedlings under the forest canopy and different temperature conditions [in Japanese with English summary]. Bull. For. For. Prod. Res. Inst. 370:1-19.

Toyoshima, K. 1938. Vegetation and useful tropical plants in the Bonin Islands [in Japanese]. Bull. For. For. Prod. Res. Inst. 36:1-251.

Vitousek, P. M. 1990. Biological invasions and ecosystem processes: Towards an integration of population biology and ecosystem studies. Oikos 57:7-13.

Vitousek, P. M., C. M. D'Antonio, L. L. Loope, M. Rejmánek, and R. Westbrooks. 1997. Introduced species: A significant component of human-caused global change. N. Z. J. Ecol. 21:1-16.

Williams, D. G., and R. A. Black. 1994. Drought response of a native and introduced Hawaiian grass. Oecologia (Berl.) 97:512-519.

Yamashita, N., A. Ishida, H. Kushima, and N. Tanaka. 2000. Acclimation to sudden increase in light favoring an invasive over native trees in subtropical islands, Japan. Oecologia (Berl.) 125:412-419.

Yamashita, N., N. Koike, and A. Ishida. 2002. Leaf ontogenetic dependence of light acclimation in invasive and native subtropical trees of different suucessional status. Plant Cell Environ. 25:1341-1356. 


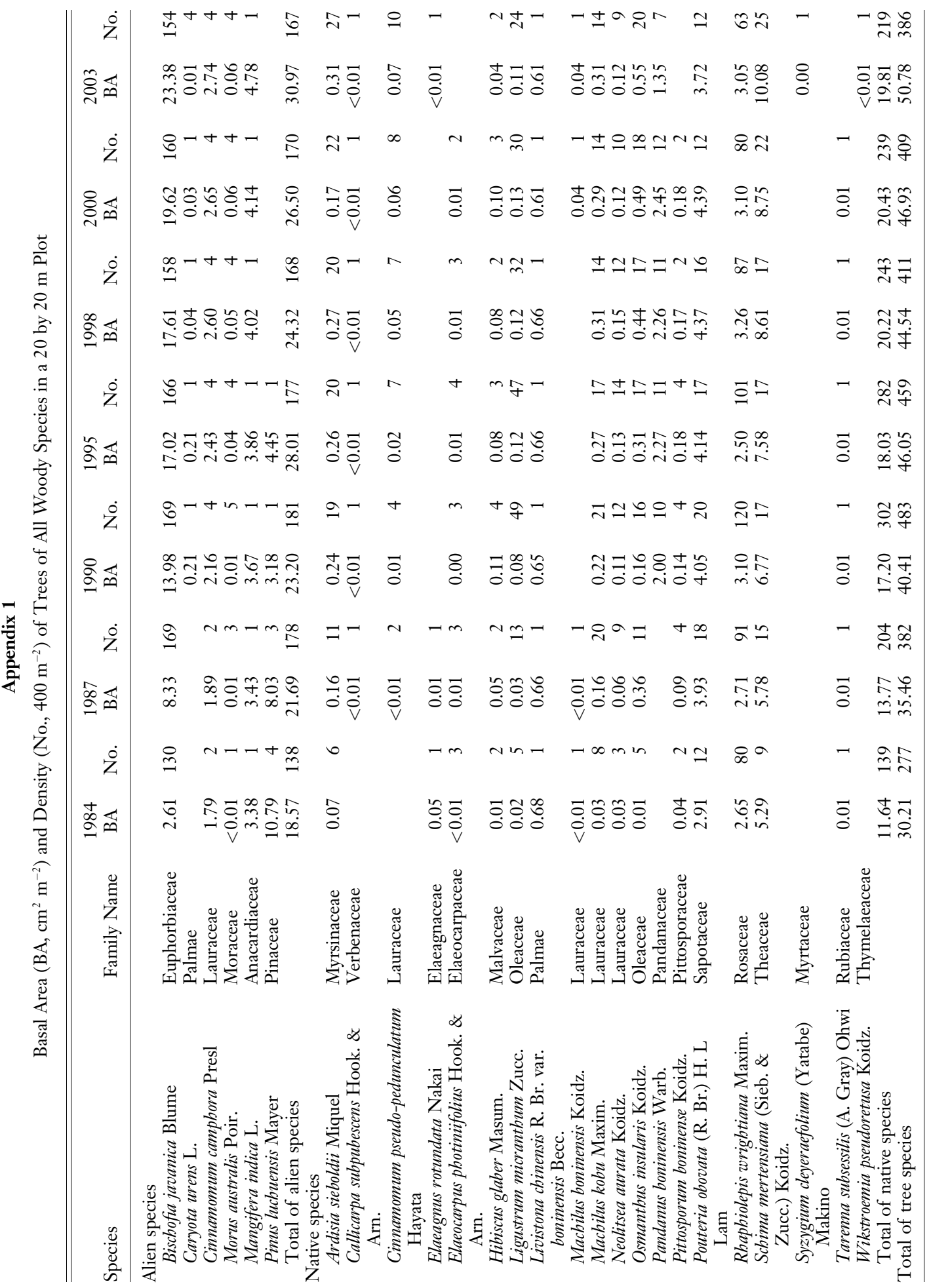


Appendix 2

Density $\left(400 \mathrm{~cm}^{-2}\right)$ of Saplings of All Woody Species in a 20 by $20 \mathrm{~m}$ Plot

\begin{tabular}{|c|c|c|c|c|c|c|c|c|}
\hline Species & Family Name & 1984 & 1987 & 1990 & 1995 & 1998 & 2000 & 2003 \\
\hline \multicolumn{9}{|l|}{ Alien species } \\
\hline Bischofia javanica Blume & Euphorbiaceae & 68 & 61 & 32 & 22 & 21 & 18 & 12 \\
\hline Caryota urens $\mathrm{L}$. & Palmae & 1 & & & & 1 & 1 & 1 \\
\hline Morus australis Poir. & Moraceae & 5 & 3 & 1 & 1 & 1 & 4 & 1 \\
\hline Psidium cattleianum Sabine & Myrtaceae & & & & & 2 & 3 & 2 \\
\hline Psidium guajava L. & Myrtaceae & & & & & & 1 & \\
\hline Total of alien species & & 74 & 64 & 33 & 23 & 25 & 27 & 16 \\
\hline \multicolumn{9}{|l|}{ Native species } \\
\hline Ardisia sieboldii Miquel & Myrsinaceae & 28 & 20 & 23 & 20 & 21 & 25 & 25 \\
\hline Callicarpa subpubescens Hook. \& Arn. & Verbenaceae & 1 & & & & & & 1 \\
\hline Celtis boninensis Koidz. & Ulmaceae & & & & & & & 1 \\
\hline $\begin{array}{l}\text { Cinnamomum pseudo-pedunculatum } \\
\text { Hayata }\end{array}$ & Lauraceae & 15 & 13 & 10 & 11 & 7 & 13 & 7 \\
\hline Elaeagnus rotundata Nakai & Elaeagnaceae & & & & & & 1 & 2 \\
\hline $\begin{array}{l}\text { Elaeocarpus photiniifolius Hook. \& } \\
\text { Arn. }\end{array}$ & Elaeocarpaceae & 5 & 2 & 2 & 1 & 2 & & \\
\hline Euonymus boninensis Koidz. & Celestraceae & 3 & 2 & 3 & & & & \\
\hline Hibiscus glaber Masum. & Malvaceae & & & & & 1 & 9 & 7 \\
\hline Ligustrum micranthum Zucc. & Oleaceae & 216 & 143 & 93 & 58 & 46 & 62 & 24 \\
\hline Machilus boninensis Koidz. & Lauraceae & 2 & 1 & 1 & 1 & 1 & & \\
\hline Machilus kobu Maxim. & Lauraceae & 20 & 16 & 11 & 9 & 12 & 17 & 17 \\
\hline Neolitsea aurata Koidz. & Lauraceae & 14 & 10 & 11 & 7 & 7 & 9 & 15 \\
\hline Osmanthus insularis Koidz. & Oleaceae & 17 & 10 & 6 & 7 & 7 & 11 & 17 \\
\hline Pandanus boninensis Warb. & Pandanaceae & 27 & 2 & 15 & 10 & 10 & 7 & 2 \\
\hline Pittosporum boninense Koidz. & Pittosporaceae & 2 & 1 & 2 & 1 & 1 & 1 & 1 \\
\hline Pouteria obovata (R. Br.) H. L Lam & Sapotaceae & 141 & 106 & 100 & 69 & 60 & 60 & 61 \\
\hline Rhaphiolepis wrightiana Maxim. & Rosaceae & 251 & 220 & 197 & 152 & 215 & 288 & 195 \\
\hline $\begin{array}{l}\text { Schima mertensiana (Sieb. \& Zucc.) } \\
\text { Koidz. }\end{array}$ & Theaceae & 11 & 10 & 10 & 9 & 10 & 14 & 14 \\
\hline $\begin{array}{l}\text { Syzygium cleyeraefolium (Yatabe) } \\
\text { Makino }\end{array}$ & Myrtaceae & 2 & 2 & 1 & 1 & & & 1 \\
\hline Tarenna subsessilis (A. Gray) Ohwi & Rubiaceae & 3 & 3 & 2 & 1 & 1 & & \\
\hline Trema orientalis Blume & Ulmaceae & 3 & & & & & & \\
\hline Wikstroemia pseudoretusa Koidz. & Thymelaeaceae & & & & 3 & 6 & 3 & \\
\hline Total of native species & & 761 & 561 & 487 & 360 & 407 & 520 & 390 \\
\hline Total of tree species & & 835 & 625 & 520 & 383 & 432 & 547 & 406 \\
\hline
\end{tabular}


Appendix 3

Species Composition of Pinus-Schima Secondary Forests after Death of P. luchuensis on Chichijima Island

\begin{tabular}{|c|c|c|c|c|c|}
\hline Species & $\begin{array}{l}\text { No. of Trees } \\
\left(\text { No. } 0.487 \mathrm{ha}^{-1}\right)\end{array}$ & $\begin{array}{l}\text { Density } \\
\left(\text { No. ha }^{-1}\right)\end{array}$ & $\begin{array}{l}\text { Basal Area } \\
\left(\mathrm{ha}^{-1}\right)\end{array}$ & $\begin{array}{l}\text { Max. DBH } \\
\quad(\mathrm{cm})\end{array}$ & $\begin{array}{c}\text { Frequency of } \\
\text { Occurrence } \\
\left(\text { No. } 35 \text { plots }^{-1}\right)\end{array}$ \\
\hline \multicolumn{6}{|l|}{ Alien species } \\
\hline Bischofia javanica Blume & 495 & $1,016.43$ & 6.37 & 63.7 & 17 \\
\hline Caryota urens $\mathrm{L}$. & 12 & 24.64 & 0.09 & 12.0 & 3 \\
\hline Casuarina equisetifolia Forst. & 1 & 2.05 & 0.02 & 11.5 & 1 \\
\hline Chrysalidocarpus lutescens $\mathrm{H}$. Wendl. & 1 & 2.05 & $<0.01$ & 4.2 & 1 \\
\hline Cinnamomum camphora (L.) J. Presl & 6 & 12.32 & 0.27 & 27.4 & 3 \\
\hline Diospyros ferrea (Willd.) Bakh. & 10 & 20.53 & $<0.01$ & 6.1 & 3 \\
\hline Leucaena leucocephala (L.) de Wit & 2 & 4.11 & $<0.01$ & 4.1 & 2 \\
\hline Mangifera indica L. & 1 & 2.05 & 0.39 & 49.4 & 1 \\
\hline Morus australis Poir. & 7 & 14.37 & 0.06 & 12.9 & 3 \\
\hline Pinus luchuensis Mayer & 40 & 82.14 & 2.17 & 59.1 & 9 \\
\hline Psidium cattleianum Sabine & 208 & 427.10 & 0.14 & 6.1 & 24 \\
\hline \multicolumn{6}{|l|}{ Native species } \\
\hline Ardisia sieboldii Miquel & 395 & 811.09 & 0.52 & 13.2 & 23 \\
\hline Boninia glabra Planchon & 2 & 4.11 & $<0.01$ & 2.8 & 1 \\
\hline Callicarpa subpubescens Hook. Et Arn. & 9 & 18.48 & 0.01 & 5.2 & 7 \\
\hline Cinnamoтит jaропісит Sieb. ex Nakai & 1 & 2.05 & $<0.01$ & 0.4 & 1 \\
\hline $\begin{array}{l}\text { Cinnamomum pseudo-pedunculatum } \\
\text { Hayata }\end{array}$ & 64 & 131.42 & 0.11 & 11.0 & 18 \\
\hline Cyathea mertensiana (Kunze) Copel. & 3 & 6.16 & 0.13 & 16.8 & 2 \\
\hline Distylium lepidotum Nakai & 10 & 20.53 & 0.01 & 4.6 & 3 \\
\hline Drypetes integerrima (Koidz.) Hurusawa & 2 & 4.11 & $<0.01$ & 5.0 & 2 \\
\hline Elaegnus rotundata Nakai & 1 & 2.05 & $<0.01$ & 0.9 & 1 \\
\hline $\begin{array}{l}\text { Elaeocarpus photiniifolius Hook. et } \\
\text { Arn. }\end{array}$ & 45 & 92.40 & 1.26 & 38.1 & 10 \\
\hline Fagara boninsimae Koidz. & 17 & 34.91 & 0.08 & 12.7 & 8 \\
\hline Ficus boninsimae koidz. & 1 & 2.05 & $<0.01$ & 0.5 & 1 \\
\hline Ficus nishimurae koidz. & 1 & 2.05 & $<0.01$ & 2.0 & 1 \\
\hline Freycinetia boninensis Nakai & 11 & 22.59 & 0.01 & 3.3 & 2 \\
\hline Geniostoma glabrum Matsum. & 1 & 2.05 & 0.02 & 11.5 & 1 \\
\hline Hernandia ovigera L. & 1 & 2.05 & $<0.01$ & 0.4 & 1 \\
\hline Hibiscus glaber Masum. & 81 & 166.32 & 1.10 & 17.7 & 9 \\
\hline Ilex mertensii Maxim. & 13 & 26.69 & 0.04 & 9.2 & 10 \\
\hline Ligustrum micrantbum Zucc. & 179 & 367.56 & 0.10 & 6.2 & 24 \\
\hline $\begin{array}{l}\text { Livistona chinensis R. Br. Var. Boninensis } \\
\text { Becc. }\end{array}$ & 29 & 59.55 & 2.09 & 28.8 & 9 \\
\hline Mahcilus boninensis Koidz. & 1 & 2.05 & $<0.01$ & 4.7 & 1 \\
\hline Machilus kobu Maxim. & 287 & 589.32 & 1.52 & 25.5 & 29 \\
\hline Neolitsea aurata Koidz. & 176 & 361.40 & 0.74 & 19.6 & 15 \\
\hline Ochrosia nakaiana Koidz. & 10 & 20.53 & 0.05 & 9.0 & 4 \\
\hline Osmanthus insularis Koidz. & 95 & 195.07 & 0.25 & 13.9 & 22 \\
\hline Pandanus boninensis Warb. & 28 & 57.49 & 0.46 & 13.8 & 10 \\
\hline Photinia wrightiana Maxim. & 8 & 16.43 & 0.01 & 2.2 & 3 \\
\hline Pisonia umbellifera Seem. & 1 & 2.05 & $<0.01$ & 0.9 & 1 \\
\hline Pouteria obovata (R. Br.) H. L Lam & 94 & 193.02 & 1.08 & 30.4 & 20 \\
\hline Rhaphiolepis wrightiana Maxim. & 436 & 895.28 & 1.48 & 23.0 & 29 \\
\hline Rhus succedanea L. & 8 & 16.43 & 0.02 & 7.6 & 3 \\
\hline $\begin{array}{l}\text { Schima mertansiana (Sieb. et Zucc.) } \\
\text { Koidz. }\end{array}$ & 1,341 & $2,753.59$ & 30.84 & 78.0 & 35 \\
\hline Syzygium cleyeraefolium (Yatabe) Makino & 61 & 125.26 & 0.14 & 10.6 & 14 \\
\hline Tarenna subsessilis (A. Grav) Ohwi & 2 & 4.11 & $<0.01$ & 1.7 & 2 \\
\hline Trema orientalis Blume & 16 & 32.85 & 0.02 & 5.5 & 2 \\
\hline Wikstroemia pseudoretusa Koidz. & 8 & 16.43 & $<0.01$ & 1.3 & 3 \\
\hline Total of tree species & 4,221 & $8,667.35$ & 51.62 & & 394 \\
\hline
\end{tabular}

